\title{
Economic Growth and Remittances Inflow: Empirical Evidence from Kyrgyz Republic
}

\author{
Nurlan ATABAEV ${ }^{*}$, Gulnaz ATABAEVA ${ }^{* *}$, Damira BAIGONUSHOVA ${ }^{* * *}$
}

\begin{abstract}
This article examines the effects of remittances inflow on economic growth in Kyrgyz Republic. We analyzed relationships between the remittances inflow, real $G D P, C P I$, exchange rate, import and international reserves by using the vector autoregression approach (VAR) and monthly data for 2005-2012. As a result it has been found that remittances inflow positively effects on output and import which lasts only for two months and negatively on exchange rate of foreign currency (dollar).
\end{abstract}

Keywords: Remittances Inflow, Economic Growth, Vector Autoregression, Exchange Rate

JEL Code Classification: F24, O4, F4

\footnotetext{
*Phd, International Ataturk Alatoo University. E-mail: nurlan.atabaev@iaau.edu.kg

***Phd Candidate, International Ataturk Alatoo University. E-mail: gulnaz.atabaeva@iaau.edu.kg

${ }^{* * *}$ Phd Candidate, Kyrgyz-Turkish Manas University. E-mail: arimad07@mail.ru
}

Copyright @ , 2014 International Ataturk Alatoo University. 


\section{Introduction}

The Central Asian economy since the late 1990s has witnessed a significant change. Socialist structure dominated by centrally planned economies of many countries has turned into a market economy structure. This transformation brought inevitable changes in economic policies, institutions and practices. This process of transformation has required the socialist and centrally planned economies to apply to a market economy in the era of globalization and open economy. Also with the breakup of the USSR, the production system running like one common economy of all member countries completely severed, and the countries has experienced a sharp decline in the production. As a result, structural changes in these countries lead to other economic problems such as unemployment and inflation. After the independence in 1991, like many other post-Soviet countries, Kyrgyz Republic inherited high level of unemployment rate and inflation from Soviet Union. It was hard for Kyrgyz Republic to transit from planned economy to market economy while poverty increased up to $62.6 \%$ in 2000 (National Statistic Committee of Kyrgyz Republic, 2013). As a solution for the poverty and high level of unemployment, Central Asian countries have been important suppliers of migrant workers for Russia who has shortage of labor due to sharply growth of economy from 2000. Kyrgyz Republic has been one of the main sources of labor for Russia and migrant workers' remittances have a great impact on economic development of the home-country. But with regard to the influence of remittance inflow on economic growth, two opposite views exist some argue that migrants' remittance has a positive influence on economic growth when others hold the opposite view. The aim of this paper is to examine the impact of labor migrants' remittances on the economic growth of Kyrgyz Republic.

The increase of migrants' remittances inflow to the Kyrgyz Republic can be explained by three factors:

- First, in the next coming 20 years migration trend from developing countries to developed countries significantly will be increased (World Bank, 2006);

- Second factor is the development of banking system due to technological improvements reduced the cost of international transaction between individuals.

- Third factor is the labor migrants mainly considered in Russia due to easing visa system, similarity in traditions, and the common language.

Number of labor migrants significantly increased from 2000 up to 2011. Remittance inflow emerged as $29 \%$ of the GDP of Kyrgyz Republic and one of the dominant sources of foreign exchange earnings which consist more than 2 bill dollars in 2012 (National Bank of Kyrgyz Republic, 2013) (Figure 1). 


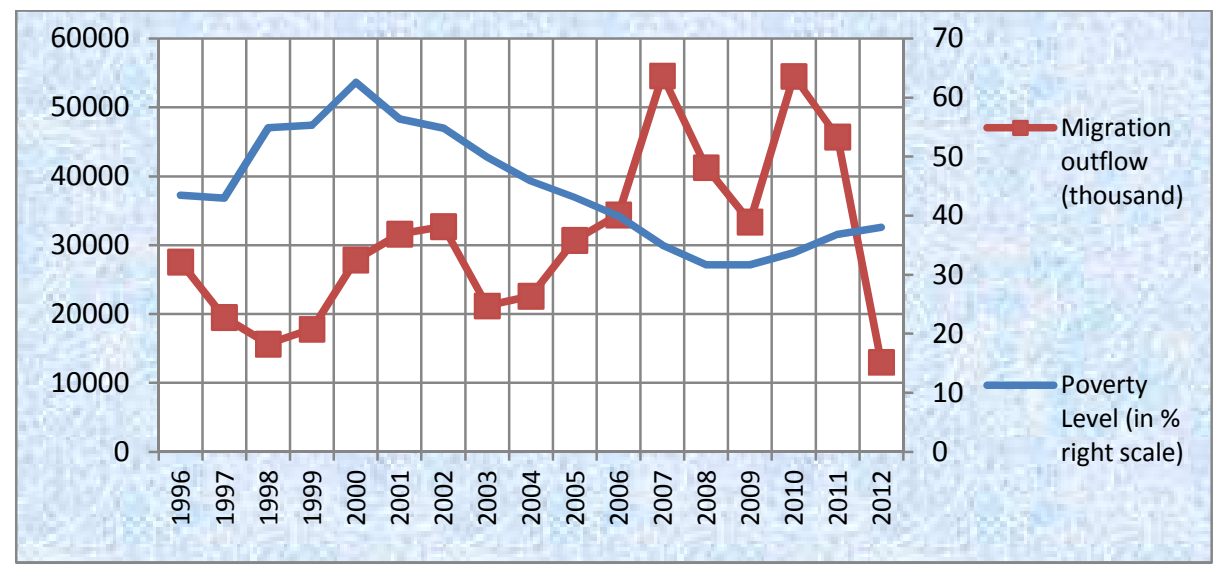

Figure 1: Migration Outflow and Poverty level, 1996-2012

Source: Formed by the authors using the data of National Statistic Committee of Kyrgyz Republic.

As seen in Figure 1, the poverty level is negatively correlated with migration outflow which proves that migrants are mainly from poor families especially from the south region of the county. Increase in remittance income help Kyrgyz Republic to minimize the poverty level and trade balance deficit and impact on exchange rate currency (dollar).

Figure 2 shows that the migrant workers' remittances inflows into Kyrgyz Republic have increased in the last 8 years. Remittance income between 2005 and 2012 increased by 6.8 times which is from 297.7 mill dollar up to 2017.9 mill dollar (National Statistic Committee of Kyrgyz Republic, 2013).

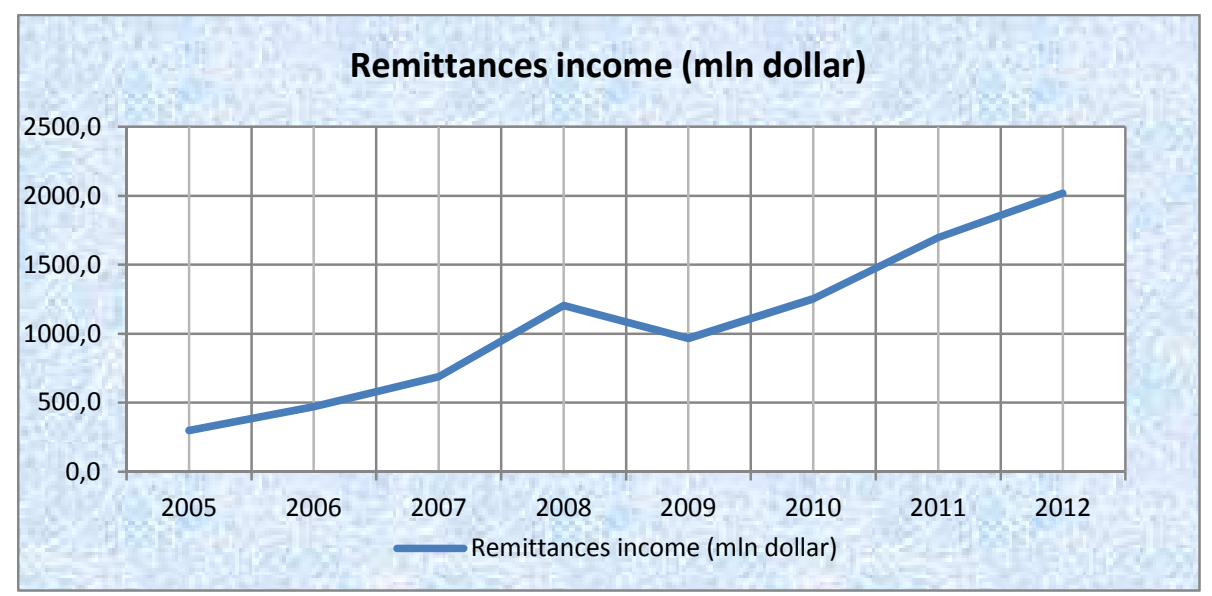

Figure 2: Migrants` Remittances to Kyrgyz Republic

Source: Formed by the authors using the National Bank of Kyrgyz Republic data. 


\section{Literature}

Many researches have been done on influence of workers' remittances on economic growth of the developing countries. Those who believe for positive impact of remittances inflow on growth of economy focus on multiplier effects of consumption (Stahl and Arnold, 1986), remittances are substituted as an alternative source for businesses where micro-financing is not available (Giuliano \& Ruiz-Arranz, 2006) and the positive effect of remittances through banking system (bank deposits and credits) to GDP (Aggarwal et al., 2006), influence of remittances on economic growth by minimizing the poverty level (Pradhan et al., 2008). Those who argue for not contribution of remittances to economic growth point out that remittance transfers are spent for everyday consumption rather than for the investment into productive assets (Rahman et al., 2006).

Results of empirical analysis in the case of transition economies show that migrant remittances are an increasingly important type of international financial flow for providing both additional resources for development as well as consumption expenditures for poverty alleviation (Shelburne \& Palacine, 2007) and have positive impact on per capita income growth, so doubling the remittances in these countries would lead to 5-9\% increase in per capita income growth (Abdullaev, 2011). Sulaimanova (2012) studied the impact of remittances on the gross domestic product of Kyrgyz Republic from 1993 to 2010, by using the method of simultaneous equations. The results of model show statistically significant positive correlation of households' final consumption with remittances. And simultaneously significant positive effect of consumption on GDP was seen.

But some researches indicate that an exogenous inflow of foreign exchange can cause "Dutch Disease", by affecting currency of the receiving country, as result of a deterioration of its competitiveness and a fall in net exports (Nikas \& Blouchoutzi, 2014).

The results of researches (Akmoldoev \& Budaichieva, 2012) on the Kyrgyz economy case by using linear correlation method and economic performance effectiveness index show that great portion of remittances has been directed into consumption rather than to investment. Moreover, remittance spending is channeled into consumption of imported goods, thus raising the trade deficit of a country. Their impact on economic effectiveness of Kyrgyzstan presents that given the low propensity to invest, they finance consumption and cause high consumption ratio with respect to investment ratio, thus leading to reduction of economic effectiveness.

Migrants' remittances inflow in foreign currencies (dollars, euros and rubles) is, in particular, responsible for the increasing dollarization (Kupets, 2012). High dollarization is a concern because it limits the effectiveness of monetary policy, increases the negative effects of budget deficits and increases the vulnerability of the banking system in the event of an economic crisis and the devaluation of the 
currency. Remittances cause income inequality among different population groups. If remittances of migrant workers come mainly in poor households, inequality is reduced, and conversely, if transfers of migrant workers arrive in wealthier households, inequality increases (Grigoryan, 2010).

Sulaimanova and Bostan (2014) showed the determinants of international migration for Tajikistan and Kyrgyzstan. The empirical results revealed that one of the strong and statistically significant pushing factors of migration is remittance inflow. Remittance is reducing migration, showing that with the growth of remittances, migration outflow decreases.

\section{Data and Methodology}

We use seasonally adjusted data from 2005/01 to 2012/12 to investigate labor workers' remittances in Kyrgyz Republic. The dataset consists of following variables:

EXRATE: exchange rate index;

CPI: Consumer price index;

GDP_NOM_SA: Index of Seasonal Adjusted with Tramo-Seats Method Nominal GDP in dollars;

GDP_REAL: Index of Real GDP;

IMPORT: Index of import;

REMIT: Index of remittances;

RESERVES: Index of international reserves:

These variable data are taken from the National Statistics Committee, and from the National Bank of Kyrgyz Republic. Augmented Dickey Fuller test has been used to eliminate the spurious regression problem and we got all variables stationary as shown in Table 1.

Table 1: ADF Unit Root Test' Results on Level Variables

\begin{tabular}{|l|c|c|c|c|c|c|}
\hline & \multicolumn{3}{|c|}{ Intercept } & \multicolumn{3}{c|}{ Trend and intercept } \\
\hline Variable & Lags & t-value & p-value & Lags & t-value & p-value \\
\hline EXRATE & 0 & $-5,29^{*}$ & 0,000 & 0 & $-5,33^{*}$ & 0,000 \\
\hline CPI & 0 & $-6,15^{*}$ & 0,000 & 0 & $-6,12^{*}$ & 0,000 \\
\hline GDP_NOM_SA & 0 & $-12,19^{*}$ & 0,000 & 0 & $-12,12^{*}$ & 0,000 \\
\hline GDP_REAL & 11 & $-3,57^{*}$ & 0,008 & 11 & $-3,18^{* *}$ & 0,026 \\
\hline IMPORT & 1 & $-11,70^{*}$ & 0,000 & 1 & $-11,72^{*}$ & 0,000 \\
\hline REMIT & 7 & $-7,60^{*}$ & 0,000 & 7 & $-7,93^{*}$ & 0,000 \\
\hline RESERVES & 0 & $-9,31^{*}$ & 0,000 & 0 & $-9,29^{*}$ & 0,000 \\
\hline
\end{tabular}

Note: ${ }^{*}$ indicates stationarity on the $1 \%$; ${ }^{* *}$ on the $5 \%$ level. $\backslash$ 
Firstly the paper analyzed the Granger causality tests where indicate an increase in a migrants ' remittances lead to an increase real GDP, imported products exchange rate and exchange rate causal to CPI as shown in Table 2.

Table 2: Pairwise Granger Causality Tests

\begin{tabular}{|l|c|c|c|}
\hline Null Hypothesis: & Obs & F-Statistic & Probability \\
\hline REMIT does not Granger Cause EXRATE & 94 & 2.40496 & 0.09611 \\
\hline REMIT does not Granger Cause GDP_REAL & 94 & 10.1739 & 0.00010 \\
\hline REMIT does not Granger Cause IMPORT & 94 & 7.58131 & 0.00091 \\
\hline EXRATE does not Granger Cause CPI & 94 & 3.57114 & 0.03222 \\
\hline
\end{tabular}

\section{Impulse Responses}

Impulse response functions indicating the impact of variables on price and output as seen in Figure 4 , with the dotted lines representing \pm 2 standard error confidence intervals and on horizons given 10 month period. The results using impulse response functions conform to those of the Granger analysis. A one - standard deviation shock to the remittances inflow effect on real output, imported products and exchange rate statistical significant. However the other variables to remittances inflow shock is insignificant.

The exchange rate is very important in a small open economy with floating exchange rates. The nominal exchange rate shock impact on price significant but the impulse response function shows that the price first 2 month response negatively than between 3 to 10 months remains positively. The paradox situation can be explained by the huge exchange rate intervention by NBKR especially when the foreign currency (USA dollar) appreciates (Atabaev \& Ganiev, 2013). In dollar appreciation NBKR sells the dollar for 2 months to smooth the price of dollar and that is why first two months response of price to nominal exchange rate is negative as shown in Figure 3.

The impulse response function positively effect on real output as anticipated and remains for 5 month but in third month effect goes negatively. One - standard deviation remittance inflow shock on real output as shown in Figure 4 statistically significant. Remittances help promote economic growth in Kyrgyz Republic but the impact last only for two month. The reason of impact remittances on output is transferred funds did not invested in long term projects. Workers' remittances are used for financing children's education, health care, for debt payments, constructions, weddings and funerals. Remittances are spent mainly on consumption and by multiplier effects increase demand for goods and activate economy. 
Economic Growth and Remittances Inflow: Empirical Evidence from Kyrgyz Republic Response Chelosky One S.D. Innovations \pm 2 S.E.

Response of EXRATE to REMIT
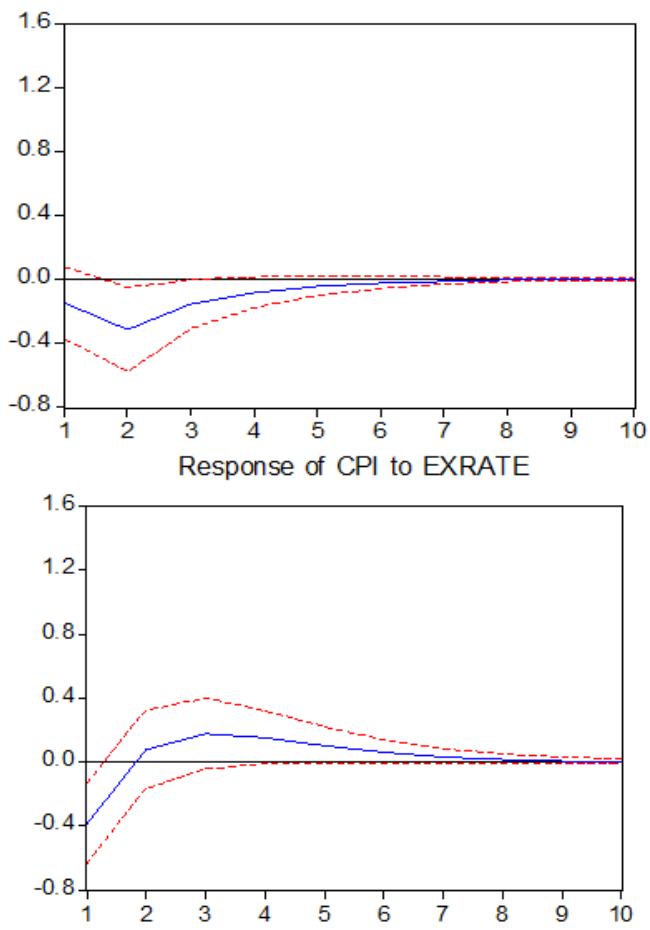

Figure 3: Impulse Response Functions to Exchange Rate and CPI

Response Chelosky One S.D. Innovations \pm 2 S.E.

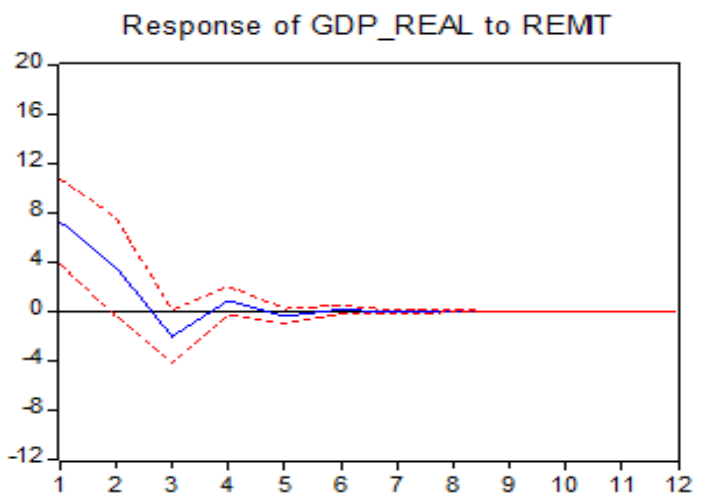

Figure 4: Impulse Response Function to Real GDP 
The remittances inflow impacts on import positively as confirmed in Figure 5.The impulse response function to import affected first 2 month positively and in third month affected negatively. The results of impulse response of output and the impulse response of import are the similar. It proofs that the remittances inflow which are spent on consumption in Kyrgyz Republic consists from imported products. That is why the impact of remittances on output is last only for two months and in 2 months the remittances money outflow as payment for imported products. Remittances inflow also helps to minimize the trade balance deficit while in Kyrgyz Republic imported products 3 times more than the exports.

Response Chelosky One S.D. Innovations \pm 2 S.E.

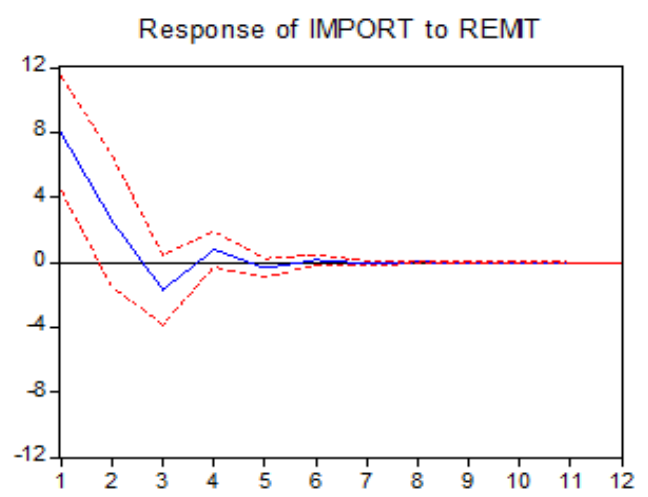

Figure 5: Impulse Response Functions to Import

\section{Conclusion}

The reasons of importance remittances inflow to exchange rate and exchange rate impact to CPI in Kyrgyz Republic:

- High level of dollarization which is officially shows $23 \%$ and unofficially counted up to70\% (saving account in foreign currency/ M2X).

- Floating exchange rate regime.

- Kyrgyz Republic is small open developing country which is highly dependent on imported products (more than $90 \%$ imported products to GDP).

It has been found that the remittances inflow impact on economic growth in Kyrgyz Republic is significant only in short run due to dependency of the country from the imported products. Another reason was the remittances inflow is spent for living and daily expenses. Remittance inflow will impact on economy in a long run if the transferred fund would be invested in long term projects and if instead of imported products would be preferred domestic products. 


\section{References}

Abdullaev, R. (2011). "Impact of remittances on economic growth in selected Asian and Former Soviet Union countries". Lund University School of Economics and Management, May 2011: 1-41

Aggarwal, R., Demirguc-Kunt, A.\& Peria, M.S.M.(2006). “Do Workers' Remittances Promote Financial Development?"World Bank Policy Research Working Paper No.3957. Available at SSRN: http://ssrn.com/abstract=923264.

Akmoldoev, K. \& Budaichieva, A. (2012). "The Impact of Remittances on Kyrgyzstan Economy", International Conference on Eurasian Economies 2012. Bishkek, Kyrgyzstan.

National Statistic Committee of Kyrgyz Republic (2013), "Kyrgyzstan in numbers-2013": 345365.

Atabaev, N. \& Ganiev, J. (2013). "Var Analysis of the Monetary Transmission Mechanism in Kyrgyzstan". Eurasian Journal of Business and Economics 6 (11): 121-132.

Giuliano, P. \& Ruiz-Arranz, M. (2006). 'Remittances, Financial Development, and Growth', IMF Working Paper No. 05/234, Washington D.C.: IMF.

Grigoryan V. A. (2010). Avtoreferat dissertacii nasoiskanie uchenoi stepeni kandidata ekonomicheskih nauk, "Mejdunarodnaya Trudovaya Migraciyai Denejniye Perevodi Migrantov: Vliyaniyena Uroven Bednostii Neravenstvo Dohodov Naseleniya Armenii", Specialnost 08.00.14 - mirovaya ekonomika, Rostov-na-Donu, 2010: 1-27/120 copies.

Kupets,O. (2012)“Razvitiye I pobochniye effekti denejnih perevodov migrantov $v$ stranah SNG: Ukraina". CARIM-East RR 2012/06, Robert Schuman Centre for Advanced Studies, San Domenico di Fiesole (FI): European University Institute.

National Bank of the Kyrgyz Republic (2013), Bulletin of National Bank of the Kyrgyz Republic 1/ 2012: 123.

Nikas, C. \& Blouchoutzi A. (2014). "Emigrants' Remittances and the "Dutch Disease" in Small Transition Economies: the Case of Albania and Moldova",Romanian Statistical Review (1/2014): 45-65

Pradhan, G., Upadhyay, M.\& Upadhyaya, K. (2008). "Remittances and economic growth in developing countries", The European Journal of Development Research 20 (3): 497-506. http://dx.doi.org/10.1080/09578810802246285

Rahman, M., Mustafa, M., Islam, A. \& Guru-Gharana, K.K. (2006). "Growth and Employment Empirics of Bangladesh", The Journal of Developing Areas 40 (1): 99-114. http://dx.doi.org/10.1353/jda.2007.0008

Stahl, C., \& Arnold, F. (1986). "Overseas Workers' Remittances in Asian Development". International Migration Review20 (4): 899-925.

http://dx.doi.org/10.2307/2545742

Shelburne, R. C. \&Palacin, J. (2007) "Remittances in the CIS: Their Economic Implications and a New Estimation Procedure", United Nations Economic Commission for Europe, Geneva, Switzerland, Discussion Paper Series No. 2007.5, November 2007: 1-53.

Sulaimanova, B. \& Bostan, A.(2014). "International Migration: A Panel Data Analysis of the Determinants of Emigration from Tajikistan and Kyrgyzstan". Eurasian Journal of Business and Economics 7 (13): 1-9. 
Sulaimanova, B. (2012). “Analiz Vliyaniya Denejnih Perevodov na Rost VVP s Ispolzovaniem Sistem Odnovremennih Ekonometricheskih Uravneniy", Reforma 3 (55): 61-66. Available at: http://journals.manas.edu.kg/reforma/oldarchives/2012-3-55/9 1907-5126-1-PB.pdf

World Bank (2006). Global Economic Prospects 2006: Economic Implications of Remittances and Migration. Washington, D.C. Available at: http://siteresources.worldbank.org/INTPROSPECTS/Resources/334934-

$1110315015165 /$ SouthSouthMigrationandRemittances.pdf (accessed: June 1, 2014) 